\title{
Visualization of the Nucleolus Using Ethynyl Uridine
}

\author{
Martina Dvoř́čcková1* and Jiři Fajkus 1,2,3* \\ ${ }^{1}$ Mendel Centre for Plant Genomics and Proteomics, Central European Institute of Technology, Masaryk University, Brno, \\ Czechia, ${ }^{2}$ Laboratory of Functional Genomics and Proteomics, National Centre for Biomolecular Research, Faculty of \\ Science, Masaryk University, Brno, Czechia, ${ }^{3}$ Institute of Biophysics, Academy of Sciences of the Czech Republic, Brno, \\ Czechia
}

Thanks to recent innovative methodologies, key cellular processes such as replication or transcription can be visualized directly in situ in intact tissues. Many studies use so-called click iT chemistry where nascent DNA can be tracked by 5-ethynyl-2'deoxyuridine (EdU), and nascent RNA by 5-ethynyl uridine (EU). While the labeling of replicating DNA by EdU has already been well established and further exploited in plants, the use of EU to reveal nascent RNA has not been developed to such an extent. In this article, we present a protocol for labeling of nucleolar RNA transcripts using EU and show that EU effectively highlights the nucleolus. The method is advantageous, because the need to prepare transgenic plants expressing fluorescently tagged nucleolar components when the nucleolus has to be visualized can be avoided.

Yasunori Machida,

Nagoya University, Japan

Reviewed by:

Taras P. Pasternak, Albert Ludwigs University of Freiburg,

Germany

Francisco Javier Medina, Consejo Superior de Investigaciones

Cientificas (CSIC), Spain

*Correspondence:

Martina Dvořáčková dvorackova.martina@gmail.com

Jiři Fajkus

jiri.fajkus@ceitec.muni.cz; fajkus@sci.muni.cz

Specialty section: This article was submitted to Plant Cell Biology,

a section of the journal

Frontiers in Plant Science

Received: 28 August 2017 Accepted: 30 January 2018

Published: 16 February 2018

Citation: Dvořáčková M and Fajkus J (2018) Visualization of the Nucleolus Using Ethynyl Uridine.

Front. Plant Sci. 9:177. doi: 10.3389/fpls.2018.00177
Keywords: nucleolus, nucleus, transcription, Arabidopsis thaliana, click iT

\section{INTRODUCTION}

The nucleus, as the most prominent cellular component, represents an important research target, and thus considerable effort has been put into establishing reliable detection methods to track nuclear processes. The most prominent structure in the plant nucleus is the nucleolus, the region where transcription of rRNA genes and processing of their transcripts occur (Stoykova et al., 1985; French and Miller, 1989; Raska et al., 1989; Scheer et al., 1997; Koberna et al., 2002). Due to their unique structure, plant and animal nucleoli have represented an attractive object for microscopy. This can be documented in a number of studies focusing on its structure, metabolism, or DNA and protein components (Jacob and Sirlin, 1964; Bernhard, 1966; Jordan and Luck, 1976; Zankl and Bernhardt, 1977; Ochs et al., 1985; Fakan and Hernandez-Verdun, 1986; Biggiogera et al., 1989; Beven et al., 1995; Kopecny et al., 1996; de Carcer and Medina, 1999).

This article will introduce a method to label nucleolar RNA in the plant model Arabidopsis thaliana. The first protocols exploring transcription took advantage of using radioactively labeled $\left[{ }^{3} \mathrm{H}\right]$ uridine detected by autoradiography (Uddin et al., 1984; Wassermann et al., 1988). With the development of halogenated nucleoside triphosphates such as 5-bromouridine$5^{\prime}$-triphosphate (BrUTP) which are detected by specific antibodies, a wide range of possible downstream applications emerged (Gratzner, 1982; Dundr and Raska, 1993; Jensen et al., 1993; Wansink et al., 1993; Chang et al., 2000). However, BrUTP is not absorbed well by living cells, and thus it has to be applied on isolated nuclei in so-called run-on assays (Thompson et al., 1997; Dhoondia et al., 2017), or introduced into cells via transfection, injection, or electroporation (Waksmundzka and Debey, 2001). Molecules such as 5-bromouridine $(\mathrm{BrU})$, 5-iodouridine (IU), or 5-fluorouridine (FU), on the other hand, are efficiently taken up by living organisms. Direct incubation of fish in FU containing sea water or its 
injection into rats enabled tracking of RNA transcription in vivo (Casafont et al., 2006; So et al., 2010). Similar approaches also led to the development of genome-wide analyses of nascent RNA, isolated via chromatin immunoprecipitation using anti-BrU antibody. This method is called the BrU immunoprecipitation chase (BRIC) assay and involves deep sequencing of the obtained RNA moieties (Tani and Akimitsu, 2012; Imamachi et al., 2014).

In A. thaliana, the application of $\mathrm{BrU}$ has not been reported so far and the above-mentioned applications remain to be explored further. One of the few studies using BrU in plants by the run-on method was implemented in Brassica napus to describe nuclear transcription (Straatman et al., 1996). BrU combined with electron microscopy helped to uncover transcription in particular domains inside the nucleolus of garden peas (Thompson et al., 1997) and recently it has been successfully applied in tobacco (Singh et al., 2017).

Because BrU, FU, or IU are detected indirectly by immunofluorescence, the novel derivative 5-ethynyl uridine (EU), which can be revealed by a click iT reaction, brought a great improvement by reducing the number of steps in the detection procedure (Dimitrova, 2011). EU was shown to be incorporated efficiently into all kinds of RNA, and HPLC revealed that every 35th nucleotide is substituted by EU (Jao and Salic, 2008). Also, relatively short pulses ( $\sim 10 \mathrm{~min})$ were sufficient to obtain visible signal in cultured cells.

The click iT reaction is a selective alkyne-azide cycloaddition where the ethynyl group of EU is covalently connected to azidecontaining molecules under $\mathrm{Cu}$ (I) catalysis (Rostovtsev et al., 2002; Tornoe et al., 2002). Individual components of click iT reactions are small, which enables their use even in whole tissues including fixed whole root tips. Because the free copper (I) present in the click iT can affect other fluorescent molecules and precludes protocols where multiple labeling is needed (Kennedy et al., 2011; Dvorackova et al., 2018), picolyl azide in combination with copper chelates without any side effects were developed, as discussed previously (Kuang et al., 2010; Uttamapinant et al., 2012).

The click iT chemistry is nowadays widely used to label replication sites by ethynyl deoxy uridine (EdU). EdU was already successfully applied in Arabidopsis, first to visualize the DNA replication phase in cultured cells (Kotogany et al., 2010; Mickelson-Young et al., 2016), and later to track S phase progression in root meristems (Hayashi et al., 2013; Yokoyama et al., 2016; Dvorackova et al., 2018) or to detect proliferation capacity (Kazda et al., 2016). It was also demonstrated that EdU persists in plant material during growth and that it could be used to track cell fate (Watson et al., 2016).

As mentioned above, the use of EU remains to be explored in plants, and here we suggest to implement EU as an in situ marker of plant nucleoli. The nucleolus delimits the nuclear territory of transcriptionally active and mostly de-condensed ribosomal genes, corresponding to approximately $1 \mathrm{Mb}$ in A. thaliana (Pruitt and Meyerowitz, 1986; Beven et al., 1995; Pontvianne et al., 2013). More traditional methods to label the plant nucleolus implement tagging of specific nucleolar proteins by fluorescent tags or raising antibodies against nucleolar proteins (e.g., Pendle et al., 2005; Pontvianne et al., 2007;
Chandrasekhara et al., 2016). In addition, due to its relatively low DNA density the nucleolus does not stain well with 4',6-diamidino-2-phenylindole dihydrochloride (DAPI) and it appears as a black hole inside the nucleus. Thus, the visualization of the nucleolus using EU is a relatively easy and fast approach, advantageous over many more demanding protocols and timeconsuming protocols.

\section{MATERIALS AND METHODS}

WT-Col0 plants and plants expressing fibrillarin-YFP (kindly provided by F. Pontvianne, CNRS, Perpignan, France) were used. Plants were grown on 1/2 Murashige-Skoog (MS; Duchefa 0255) plates with $1 \%$ plant agar (Duchefa) and $1 \%$ sucrose. The growth conditions were: $8 \mathrm{~h} / 16 \mathrm{~h}$ light/dark, $22^{\circ} \mathrm{C}$, and light intensity $100 \mu \mathrm{mol} \mathrm{m}^{-2} \mathrm{~s}^{-1}$.

\section{EU Labeling}

Two types of EU were used in this study, product CLK-N00210 (Jena Bioscience, $200 \mathrm{mM}$ in sterile water) and E-10345 (Life Technologies, $100 \mathrm{mM}$ in DMSO). Four days old A. thaliana seedlings were transferred into 12 -well plates (Greiner Bio-One). Each well contained $2 \mathrm{ml}$ of the liquid growth medium (1/2 MS). When CLK-N002-10 product was used, $20 \mu \mathrm{l}$ of DMSO was added to the media to keep the same conditions as for the E10345 product. Although DMSO is not required for efficient EU labeling, when the product E-10345 (diluted in DMSO) is used, seedlings are always exposed to $1 \%$ DMSO. Thus, when developmental studies or long EU incubation are performed, DMSO should be kept as low as $0.1 \%$ to avoid its potential side effects on the root growth (Shibasaki et al., 2009; Zhang et al., 2016). In such cases, the use of CLK-N002-10 product (diluted in water) is recommended. Alternatively, product E- 10345 can be prepared as $0.5 \mathrm{M}$ stock solution to decrease the DMSO content in the media.

Seedlings were labeled by adding $10 \mu \mathrm{M}, 50 \mu \mathrm{M}, 500 \mu \mathrm{M}$, or $1 \mathrm{mM}$ EU into the liquid growth medium and incubated for the required time. The incubation was performed avoiding direct light.

\section{Fixation}

5-Ethynyl uridine-labeled seedlings were fixed in freshly made $4 \%$ formaldehyde $/ 1 \times \mathrm{PBS} / 0.5 \%$ Triton X-100 solution for $20 \mathrm{~min}$, followed by $4 \%$ formaldehyde/1× PBS/1\% Triton X-100 for an additional $25 \mathrm{~min}$. The first $2 \mathrm{~min}$ of fixation was performed under vacuum (0.7 bar) in a plastic desiccator (Kartell). The $1 \times$ PBS buffer contained $137 \mathrm{mM} \mathrm{NaCl}, 2.7 \mathrm{mM} \mathrm{KCl}, 10 \mathrm{mM}$ $\mathrm{Na}_{2} \mathrm{HPO}_{4}$, and $1.8 \mathrm{mM} \mathrm{KH}_{2} \mathrm{PO}_{4}$, pH 7.4. Formaldehyde solution (8\%) was made by dissolving $0.8 \mathrm{~g}$ of paraformaldehyde (Sigma P6148) in $10 \mathrm{ml}$ of distilled water containing $100 \mu \mathrm{l}$ of $1 \mathrm{M}$ $\mathrm{NaOH}$ and heated up to $60^{\circ} \mathrm{C}$ in the exhaust hood; the $\mathrm{pH}$ was then adjusted to 8.0 and the solution was filtered using Whatman filter paper. After fixation, seedlings were washed for $1 \times 10 \mathrm{~min}$ in $1 \times \mathrm{PBS}, 1 \times 10 \mathrm{~min}$ in $1 \times \mathrm{PBS} / 135 \mathrm{mM}$ glycine, and $10 \mathrm{~min}$ in $1 \times \mathrm{PBS}$, and proceeded directly to the click-iT reaction. 


\section{Click iT Reaction}

5-Ethynyl uridine-labeled and fixed seedlings were incubated with $500 \mu \mathrm{l}-1 \mathrm{ml}$ of click iT mixture containing $1 \times$ PBS, $4 \mathrm{mM}$ $\mathrm{CuSO}_{4}, 5 \mu \mathrm{M}$ AF488 azide (Thermo Fisher Scientific, A10266), and $40 \mathrm{mM}$ sodium ascorbate (Applichem A5048.0100, freshly prepared as a $400 \mathrm{mM}$ solution and added into the click iT mixture at the required amount). The reaction was incubated for $1 \mathrm{~h}$ at room temperature in the dark and followed by two 5 min washes in $1 \times$ PBS. Alternatively, an Alexa Fluor 488 picolyl azide 488 toolkit (Thermo Fisher Scientific C10641) was used instead of the Alexa Fluor 488 azide protocol. This toolkit was developed to avoid quenching of fluorescent molecules caused by free copper present in the click iT reaction. It employs picolyl azide instead of azide and a protected copper solution. We efficiently used the picolyl azide provided in the C10641 kit as well as picolyl azide sulfo Cy5 (Jena Bioscience, CLK-1177). The reaction mixture was prepared according to the manufacturer's protocol, using a copper:protected copper ratio of 1:1.

\section{DAPI Staining}

4,6-Diamidino-2-phenylindole dihydrochloride (DAPI, $1 \mathrm{mg} \mathrm{ml}^{-1}$; Serva) was added to the seedlings after performing the click iT reaction to a final concentration of $1 \mu \mathrm{g} \mathrm{ml}^{-1}$ and incubated overnight in the refrigerator in the dark. The excess of DAPI was removed by two washes in $1 \times$ PBS. Shorter incubation with DAPI is recommended when the overnight incubation produces a high background noise.

\section{Nuclei Preparation}

Overnight EU-labeled root tips were excised and fixed in freshly made ice-cold ethanol:acetic acid (3:1) fixative for $24 \mathrm{~h}$. The fixative was exchanged once during this time. Roots were then washed $1 \times 5 \mathrm{~min}$ in distilled water, $2 \times 5 \mathrm{~min}$ in $10 \mathrm{mM}$ citrate buffer $(4 \mathrm{mM}$ citric acid and $6 \mathrm{mM}$ sodium citrate, $\mathrm{pH}$ 4.5), and digested by a mixture of cellulase (Onozuka R10, Serva 16419.03), pectolyase (Duchefa, P8004.0001), and cytohelicase (Sigma, C8274), 0.3\% (w/v) each in $10 \mathrm{mM}$ citrate buffer, for $25 \mathrm{~min}$ at $37^{\circ} \mathrm{C}$. Digested root tips were washed once in citrate

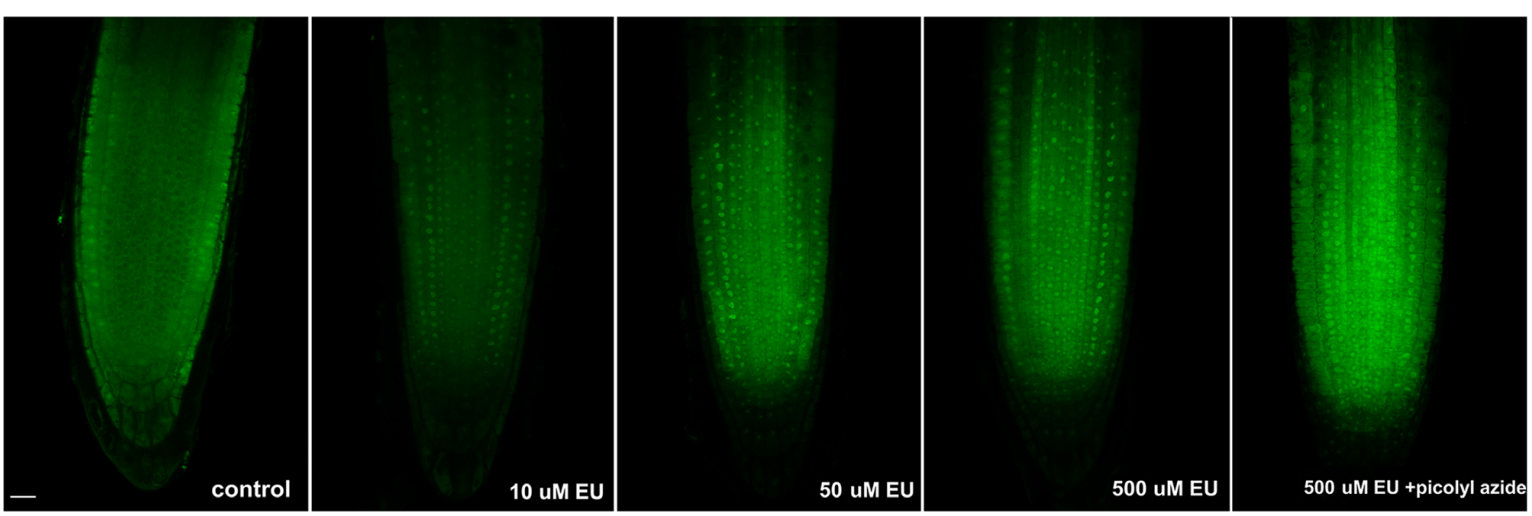

FIGURE 1 | Long EU pulses. Arabidopsis 4 days old seedlings were incubated overnight avoiding direct light with an increasing concentration of EU (Jena Bioscience) and EU-containing RNA was detected by the click iT reaction. The last image in the row shows the result of a modified detection protocol using AF488 picolyl azide instead of AF488 azide. Confocal sections in the middle part of the root are shown. Bar $=10 \mu \mathrm{m}$.

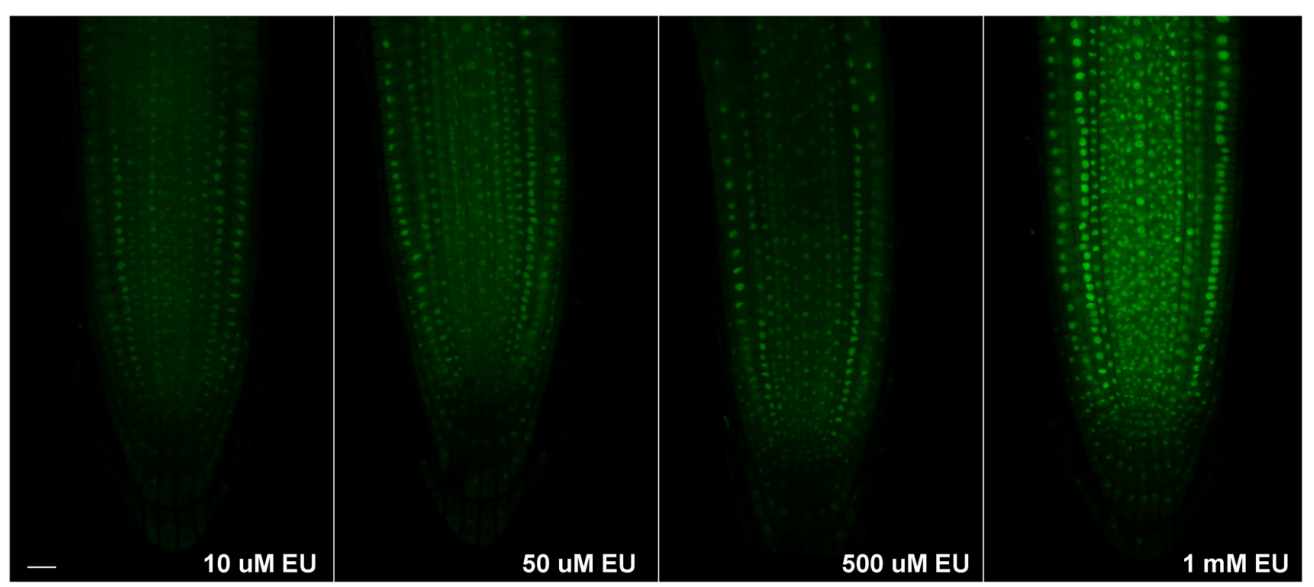

FIGURE 2 | Short EU pulses. Arabidopsis 4 days old seedlings were incubated avoiding direct light for 2 h with an increasing concentration of EU (Jena Bioscience) and EU-containing RNA was detected by the click iT reaction. Confocal sections in the middle part of the root are shown. Bar $=10 \mu \mathrm{m}$ 
buffer and transferred to slides. After complete removal of the citrate buffer, root tips were squashed in a drop of $50 \%$ acetic acid. Cover slips were removed in liquid nitrogen, and slides were re-fixed in fresh ethanol:acetic acid fixative and air dried. The click iT reaction to detect EU by fluorescence was performed as described above, $200 \mu \mathrm{l}$ of click iT mixture was applied on each slide. Slides were then washed $3 \times 5 \mathrm{~min}$ in $1 \times \mathrm{PBS}$ and stained with DAPI in Vectashield $\left(1 \mu \mathrm{g} \mathrm{ml}^{-1}\right.$, Vector Laboratories, H100).

\section{Actinomycin D Treatment}

To inhibit transcription, Actinomycin D (ActD, Sigma, A1410, $1 \mathrm{mg} \mathrm{ml}^{-1}$ in DMSO) was added to the $1 / 2 \mathrm{MS} / 0.5 \%$ sucrose liquid medium in 6-well plates (Greiner Bio-One) to a final concentration of $25 \mu \mathrm{g} \mathrm{ml}^{-1}$. Four days old seedlings were incubated for $2 \mathrm{~h}$ with ActD, then for $2 \mathrm{~h}$ with $1 \mathrm{mM} \mathrm{EU}$, and processed as stated above.

\section{Microscopy}

Root tips were transferred onto slides with a drop of water, covered with coverslips, and imaged on a Zeiss LSM780 confocal microscope using a $40 \times$ C-Apochromat/1.20 W objective and Z-stacks of 1.0-1.4 $\mu \mathrm{m}$ step size, pinhole 66-68 $\mu \mathrm{m}$. Alternatively, a Zeiss Axioimager Z1 with filters corresponding to DAPI and AF488 excitation and emission spectra (AHF Analysentechnik ${ }^{1}$ ) was used. Image processing was done in Image ${ }^{2}$.

\section{RESULTS AND DISCUSSION}

\section{EU Labeling of Nucleolar Processes Visualization of Nucleolar Transcription}

The majority of RNA transcripts in the plant nucleus correspond to the rRNA genes. RNA polymerase I, the enzyme responsible for rRNA transcription inside the nucleolus, can be efficiently blocked by ActD leading to the re-distribution of nucleolar proteins and nucleolar fragmentation (Yung et al., 1990; Chen and Jiang, 2004). Efforts to detect rRNA synthesis by qPCR after ActD treatment are biased, likely due to pleiotropic effects of ActD on other RNAs including transcripts of the reference genes, as discussed (e.g., Turner et al., 2012). Here, we present an assay to detect rRNA transcription in situ using 5-EU and test the protocol on ActD-treated seedlings.

\section{Overnight EU Labeling}

Initially, EU was applied on 4 days old seedlings at different concentrations $(10,50$, and $500 \mu \mathrm{M})$, incubated overnight, and detected by the click iT reaction (Figure 1). The fixation step in the protocol included incubation of seedlings with higher concentration of Triton X-100 (compared to standard protocols) to facilitate the penetration of the click iT components into the nucleolus. All labeling pulses showed a similar labeling pattern, and a small round area inside the nucleus was observed in

${ }^{1}$ http://www.ahf.de/

${ }^{2}$ http://imagej.nih.gov/ij/ each cell, as expected for a nucleolar signal (Figure 1). A better signal-to-noise ratio was achieved when lower EU concentrations were used, probably indicating that an excess of EU contributes to the background noise signal or that the signal becomes redistributed. The presence of cytoplasmic signal was also observed in other tested species after long incubation likely reflecting the RNA dynamics in the cell (Jao and Salic, 2008).

We next tested whether the modified version of the click iT reaction using picolyl azide and protected copper (instead of azide and reactive copper species) that is required when quenching has to be inhibited (e.g., in double labeling protocols including fluorescently tagged proteins or flow cytometry) was similarly efficient in EU detection. As shown in Figure 1, the modified click iT reaction produced satisfactory signal intensity similar to the standard click iT detection method. This shows that in addition to visualization of the nucleolus, the method could be efficiently used, e.g., in flow cytometry or for double labeling protocols. Since the size of nucleoli differs in different cell types, the protocol could be further exploited to measure, for example, the size of the nucleoli. Also, in combination with fluorescence-activated cell sorting, rDNA transcription can be further evaluated at the single cell level.

\section{Short EU Pulses}

To allow for detection of ongoing transcription, shorter EU pulses were necessary. Thus, the EU labeling was repeated again with three different concentrations of EU (10, 50, and $500 \mu \mathrm{M}$ ) and the labeling time shortened to $2 \mathrm{~h}$. While

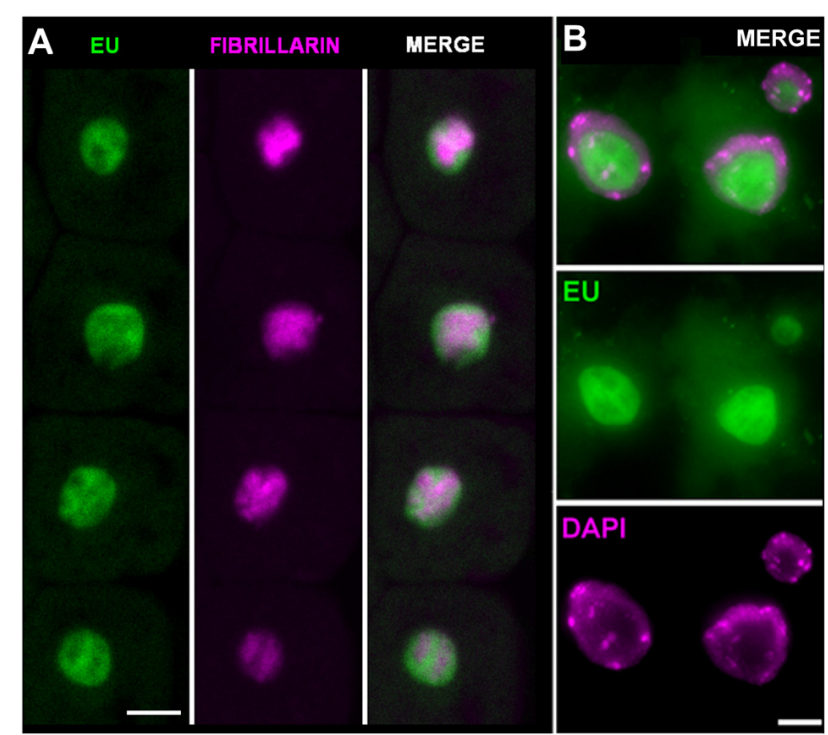

FIGURE 3 | Ethynyl uridine-containing RNA accumulates in the nucleolus. (A) Arabidopsis seedlings expressing fibrillarin-YFP (magenta) were labeled with $1 \mathrm{mM}$ EU (Invitrogen, green) for $2 \mathrm{~h}$ and EU-containing RNA was detected by the click iT reaction. Selected sections from confocal $Z$-stacks are shown. Bar $=5 \mu \mathrm{m}$. (B) Cytological spread of EU (green) and DAPI (magenta) labeled nuclei from root tip incubated avoiding direct light with EU overnight. The detailed nucleolar structure is detectable. Bar $=5 \mu \mathrm{m}$. 

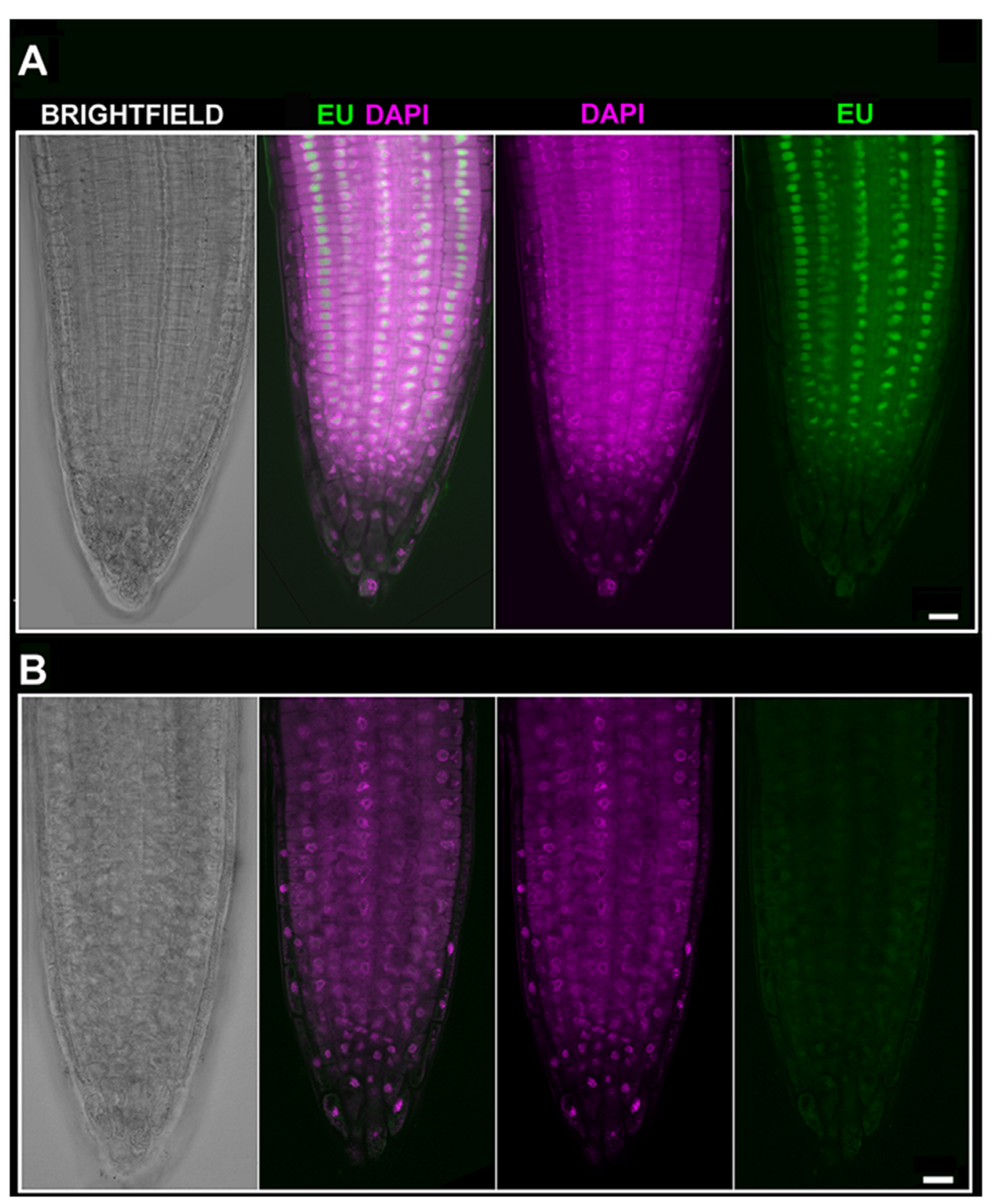

FIGURE 4 | EU signal diminishes after Actinomycin D (ActD) treatment. (A) Arabidopsis 4 days old seedlings were incubated without pre-treatment for 2 h with $1 \mathrm{mM}$ EU (Invitrogen, green) avoiding direct light, detected by click iT reaction and stained with DAPI (magenta). Confocal sections in the middle part of the root are shown. Bar $=10 \mu \mathrm{m}$. (B) Arabidopsis 4 days old seedlings were treated for $2 \mathrm{~h}$ with ActD prior to EU labeling. DAPI (magenta), EU (green). Selected sections from confocal Z-stacks are shown. Bar $=10 \mu \mathrm{m}$.

$10 \mu \mathrm{M}$ EU produced a rather weak signal, 50 and $500 \mu \mathrm{M}$ EU were brighter (Figure 2). The signal-to-noise ratio, however, was not satisfactory and needed improvement. Finally, the optimal concentration for short EU pulses was set to $1 \mathrm{mM}$ (Figure 2) which provided the expected result. The EU signal appeared not only in the root tip, but also in some leaf cells as shown in Supplementary Figure 1. Since the signal was not seen in hypocotyls, it is likely that leaves can absorb EU via stomata.

To confirm in more detail where the observed EU signal accumulates, two additional experiments were performed. First, fibrillarin-YFP expressing plants were EU labeled and signal overlap between the fibrillarin and EU was assessed (Figure 3A). Second, double EU/DAPI was applied along with EU labeling (Figure 3B). The best DAPI signal was achieved by overnight incubation of fixed seedlings with a low DAPI concentration $\left(1 \mu \mathrm{g} \mathrm{ml}^{-1}\right)$ followed by two washes with $1 \times$ PBS.
Both experiments show that the majority of the detectable signal occurs in the nucleolus, and the DAPI staining confirmed that signal in the nucleoplasm cannot be detected. The nucleolar signal does not entirely overlap with fibrillarin. In fact, it is largely accumulated in areas with a lower fibrillarin density and expands outside the area delimited by the fibrillarin. This EU distribution seems to reflect compartmentalization of the processes in the nucleolus. Pre-rRNA is mostly transcribed at the periphery of the fibrillar centers, while fibrillarin occurs in the dense fibrillar component (see e.g., Jordan, 1984; Ochs et al., 1985; Beven et al., 1995; de Carcer and Medina, 1999; Raska et al., 2006; Montanaro et al., 2011).

It is interesting that a similar labeling pattern is achieved using short or long EU pulses and that the EU signal is detectable exclusively inside the nucleolus and in its vicinity. These results are contrary to the EU pattern observed in cell cultures, where nuclear signal is detected along with strong nucleolar labeling 


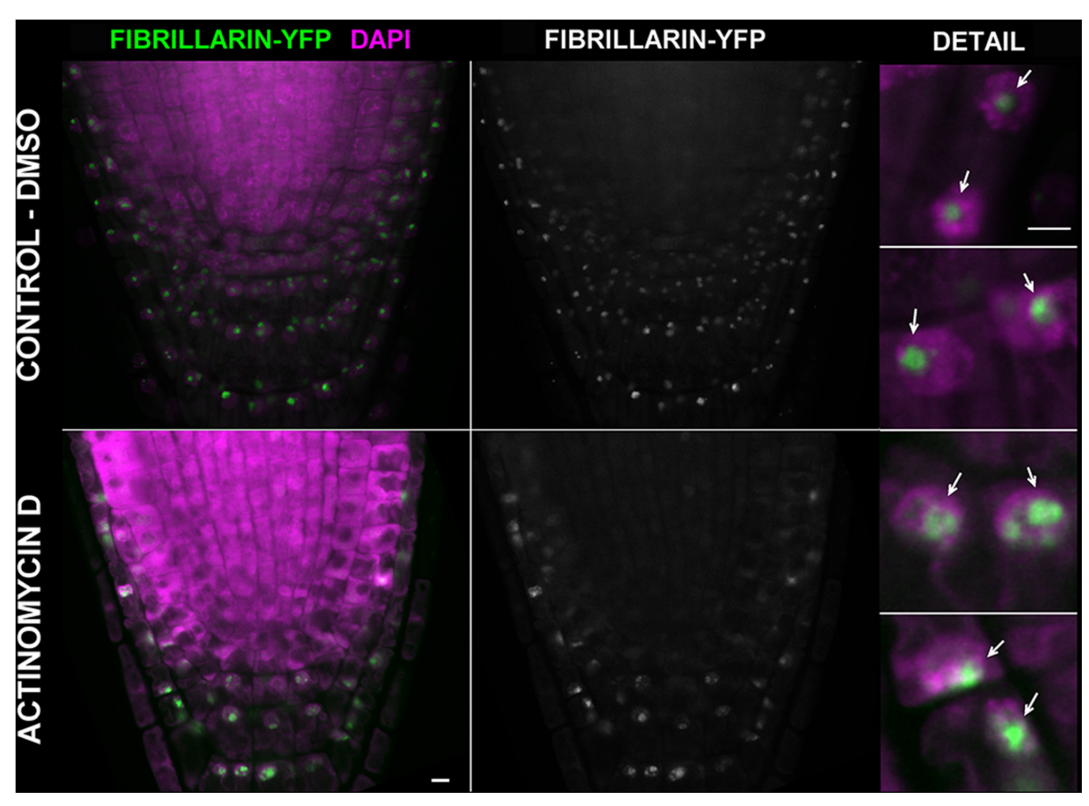

FIGURE 5 | Actinomycin D causes re-distribution of fibrillarin. Arabidopsis 4 days old seedlings expressing fibrillarin-YFP (green) were treated with $25 \mu \mathrm{g} \mathrm{ml}^{-1}$ of ActD for $2 \mathrm{~h}$ (the bottom panel). In the upper panel, a control incubated in the solvent (2.5\% DMSO) is shown. Roots were fixed, stained with DAPI (magenta), and imaged on a confocal microscope. Selected sections from confocal Z-stacks are shown. Arrows point to the nucleoli. Bar $=5 \mu \mathrm{m}$.

(Jao and Salic, 2008). Also, the same study reported that the rRNAs are labeled with a lower efficiency, while labeling of poly(A)-containing mRNAs was more profound. In our in situ experiments, it seems that the rRNA fraction is the only labeled RNA. This might suggest a relatively high turnover of labeled RNA in Arabidopsis cells, or a sensitivity issue in the protocol. It may be necessary to amplify fluorescent signal by biotinstreptavidin system or antibodies to reveal remaining RNA transcripts. Also, during the fixation, higher amounts of Triton X100 were used, which could possibly cause the re-distribution of nuclear RNAs into the cytoplasm. It is possible that signal would be more stabilized if the detection is performed on isolated nuclei instead of the whole root, requiring stronger permeabilization step in the protocol. We confirmed that RNA turnover was very fast by pulse-chase experiment. When we incubated seedlings for $2 \mathrm{~h}$ in EU followed by 3 or $6 \mathrm{~h}$ incubation in EU-free $1 / 2$ MS medium, no signal was detected (Supplementary Figure 2). Although decreased stability of EU-containing RNA in plant tissue has not been reported, it could not be completely neglected. We observed, for example, that when EU-labeled material is stored, after some time the signal diminishes, but when similar material is stored after EdU labeling, this phenomenon does not occur. We also tested whether light could affect the EU stability. However, incubation of seedlings in dark or light does not seem to have any strong effect on EU labeling (Supplementary Figure 3).

\section{Actinomycin D Blocks Nucleolar Transcription}

We next asked whether inhibition of transcription could be monitored by using EU. The effect of ActD on RNA pol I which further changes the nucleolar structure has been long known (Unuma et al., 1972; Kramer, 1980). Thus, we treated
Arabidopsis seedlings with ActD prior to the EU incubation. When EU was added after $2 \mathrm{~h}$ of ActD treatment, no RNA transcripts were detected indicating that ActD acted in the expected manner (Figure 4). To further characterize the effect of ActD on plant nucleoli, nucleolar integrity was monitored by fibrillarin-YFP after ActD treatment (Figure 5). After $2 \mathrm{~h}$ of ActD, fibrillarin started to re-localize from the nucleolus, confirming the sensitivity of the nucleolus to this drug as well as proving that the EU signal corresponds to the nascent RNA transcripts.

As we demonstrate here, labeling of the nucleolus by 5 -EU represents a reliable protocol applicable to monitor nucleolar transcription directly in the root tip. The protocol can be used to track potential rRNA transcription inhibitors or rRNA metabolism under various stress conditions. Due to the elevated protein density inside the nucleolus the procedure requires relatively high detergent concentrations. In addition, high EU concentrations are required when shorter EU pulses are used. Thus, possible side effects need to be considered in each experimental set-up.

\section{CONCLUSION}

Developments in microscopic approaches and their combinations with tissue- and cell-type-specific labeling and nuclei sorting allow for description of previously unknown details of key cellular processes in situ or in vivo at a high spatiotemporal resolution. This new knowledge is obtained at the cost of three factors: the increasing complexity of experiments, the high cost of instrumentation, and the need for careful optimization of methods for a given purpose and model system. 
While the first two factors can be efficiently managed in current well-established research centers, optimization remains challenging and the most time-consuming part of these experiments. Therefore, we describe here the optimized approach to visualize transcription in nucleoli of $A$. thaliana in situ to share this experience with the plant science community.

\section{AUTHOR CONTRIBUTIONS}

MD designed the experiments and performed the optimization of the protocol and all experiments. JF and MD contributed to the concept of the project and data interpretation, prepared the manuscript, and co-supervised the project.

\section{FUNDING}

This work was supported by the Czech Science Foundation (projects 16-04166Y and 16-01137S); by the Ministry of

\section{REFERENCES}

Bernhard, W. (1966). Ultrastructural aspects of the normal and pathological nucleolus in mammalian cells. Natl. Cancer Inst. Monogr. 23, 13-38.

Beven, A. F., Simpson, G. G., Brown, J. W., and Shaw, P. J. (1995). The organization of spliceosomal components in the nuclei of higher plants. J. Cell Sci. 108(Pt 2), 509-518.

Biggiogera, M., Fakan, S., Kaufmann, S. H., Black, A., Shaper, J. H., and Busch, H. (1989). Simultaneous immunoelectron microscopic visualization of protein B23 and C23 distribution in the HeLa cell nucleolus. J. Histochem. Cytochem. 37, 1371-1374. doi: 10.1177/37.9.2768807

Casafont, I., Navascues, J., Pena, E., Lafarga, M., and Berciano, M. T. (2006). Nuclear organization and dynamics of transcription sites in rat sensory ganglia neurons detected by incorporation of 5'-fluorouridine into nascent RNA. Neuroscience 140, 453-462. doi: 10.1016/j.neuroscience.2006. 02.030

Chandrasekhara, C., Mohannath, G., Blevins, T., Pontvianne, F., and Pikaard, C. S. (2016). Chromosome-specific NOR inactivation explains selective rRNA gene silencing and dosage control in Arabidopsis. Genes Dev. 30, 177-190. doi: $10.1101 /$ gad.273755.115

Chang, W. Y., Winegarden, N. A., Paraiso, J. P., Stevens, M. L., and Westwood, J. T. (2000). Visualization of nascent transcripts on Drosophila polytene chromosomes using BrUTP incorporation. Biotechniques 29, 934-936.

Chen, M., and Jiang, P. (2004). Altered subcellular distribution of nucleolar protein fibrillarin by actinomycin D in HEp-2 cells. Acta Pharmacol. Sin. 25, 902-906.

de Carcer, G., and Medina, F. J. (1999). Simultaneous localization of transcription and early processing markers allows dissection of functional domains in the plant cell nucleolus. J. Struct. Biol. 128, 139-151. doi: 10.1006/jsbi.1999. 4187

Dhoondia, Z., Tarockoff, R., Alhusini, N., Medler, S., Agarwal, N., and Ansari, A. (2017). Analysis of termination of transcription using BrUTP-strand-specific transcription run-on (TRO) approach. J. Vis. Exp. 121:e55446. doi: 10.3791/ 55446

Dimitrova, D. S. (2011). DNA replication initiation patterns and spatial dynamics of the human ribosomal RNA gene loci. J. Cell Sci. 124(Pt 16), 2743-2752. doi: $10.1242 /$ jcs. 082230

Dundr, M., and Raska, I. (1993). Nonisotopic ultrastructural mapping of transcription sites within the nucleolus. Exp. Cell Res. 208, 275-281. doi: 10. 1006/excr.1993.1247

Dvořáčková, M., Raposo, B., Matula, P., Fuchs, J., Schubert, V., Peška, V., et al. (2018). Replication of ribosomal DNA in Arabidopsis occurs both inside and outside of the nucleolus during S-phase progression. J. Cell Sci. 131:jcs.202416. doi: $10.1242 /$ jcs. 202416
Education, Youth and Sports of the Czech Republic under the project CEITEC 2020 (LQ1601), and by the project SYMBIT Reg. No. CZ.02.1.01/0.0/0.0/15_003/0000477 financed by the ERDF.

\section{ACKNOWLEDGMENTS}

We would like to thank F. Pontvianne for providing us with the necessary seeds and Prof. Hancock for the language revision. We acknowledge the core facility CELLIM of CEITEC supported by the MEYS CR (LM2015062 Czech-BioImaging).

\section{SUPPLEMENTARY MATERIAL}

The Supplementary Material for this article can be found online at: https://www.frontiersin.org/articles/10.3389/fpls.2018.00177/ full\#supplementary-material

Fakan, S., and Hernandez-Verdun, D. (1986). The nucleolus and the nucleolar organizer regions. Biol. Cell 56, 189-205. doi: 10.1111/j.1768-322X.1986. tb00452.x

French, S. L., and Miller, O. L. Jr. (1989). Transcription mapping of the Escherichia coli chromosome by electron microscopy. J. Bacteriol. 171, 4207-4216. doi: 10.1128/jb.171.8.4207-4216.1989

Gratzner, H. G. (1982). Monoclonal antibody to 5-bromo- and 5iododeoxyuridine: a new reagent for detection of DNA replication. Science 218, 474-475. doi: 10.1126/science.7123245

Hayashi, K., Hasegawa, J., and Matsunaga, S. (2013). The boundary of the meristematic and elongation zones in roots: endoreduplication precedes rapid cell expansion. Sci. Rep. 3:2723. doi: 10.1038/srep02723

Imamachi, N., Tani, H., Mizutani, R., Imamura, K., Irie, T., Suzuki, Y., et al. (2014). BRIC-seq: a genome-wide approach for determining RNA stability in mammalian cells. Methods 67, 55-63. doi: 10.1016/j.ymeth.2013.07.014

Jacob, J., and Sirlin, J. L. (1964). Electron microscope autoradiography of the nucleolus of insect salivary gland cells. Nature 202, 622-623. doi: 10.1038/ 202622b0

Jao, C. Y., and Salic, A. (2008). Exploring RNA transcription and turnover in vivo by using click chemistry. Proc. Natl. Acad. Sci. U.S.A. 105, 15779-15784. doi: $10.1073 /$ pnas.0808480105

Jensen, P. O., Larsen, J., and Larsen, J. K. (1993). Flow cytometric measurement of RNA synthesis based on bromouridine labelling and combined with measurement of DNA content or cell surface antigen. Acta Oncol. 32, 521-524. doi: 10.3109/02841869309096111

Jordan, E. G. (1984). Nucleolar nomenclature. J. Cell Sci. 67, 217-220.

Jordan, E. G., and Luck, B. T. (1976). The nucleolus organizer and the synaptonemal complex in Endymion non-scriptus (L.). J Cell Sci 22, 75-86.

Kazda, A., Akimcheva, S., Watson, J. M., and Riha, K. (2016). Cell proliferation analysis using EdU labeling in whole plant and histological samples of Arabidopsis. Methods Mol. Biol. 1370, 169-182. doi: 10.1007/978-1-4939-3142$2 \_13$

Kennedy, D. C., McKay, C. S., Legault, M. C., Danielson, D. C., Blake, J. A., Pegoraro, A. F., et al. (2011). Cellular consequences of copper complexes used to catalyze bioorthogonal click reactions. J. Am. Chem. Soc. 133, 17993-18001. doi: $10.1021 /$ ja2083027

Koberna, K., Malinsky, J., Pliss, A., Masata, M., Vecerova, J., Fialova, M., et al. (2002). Ribosomal genes in focus: new transcripts label the dense fibrillar components and form clusters indicative of "Christmas trees" in situ. J. Cell Biol. 157, 743-748. doi: 10.1083/jcb.200202007

Kopecny, V., Landa, V., Malatesta, M., Martin, T. E., and Fakan, S. (1996). Immunoelectron microscope analyses of rat germinal vesicle-stage oocyte nucleolus-like bodies. Reprod. Nutr. Dev. 36, 667-679. 
Kotogany, E., Dudits, D., Horvath, G. V., and Ayaydin, F. (2010). A rapid and robust assay for detection of S-phase cell cycle progression in plant cells and tissues by using ethynyl deoxyuridine. Plant Methods 6:5. doi: 10.1186/17464811-6-5

Kramer, B. (1980). The effect of actinomycin D on the nucleolus and on pigment synthesis in pigment cells of Xenopus laevis: an ultrastructural study. J. Anat. 130(Pt 4), 809-820.

Kuang, G. C., Michaels, H. A., Simmons, J. T., Clark, R. J., and Zhu, L. (2010). Chelation-assisted, copper(II)-acetate-accelerated azide-alkyne cycloaddition. J. Org. Chem. 75, 6540-6548. doi: 10.1021/jo101305m

Mickelson-Young, L., Wear, E., Mulvaney, P., Lee, T. J., Szymanski, E. S., Allen, G., et al. (2016). A flow cytometric method for estimating S-phase duration in plants. J. Exp. Bot. 67, 6077-6087. doi: 10.1093/jxb/erw367

Montanaro, L., Govoni, M., Orrico, C., Trere, D., and Derenzini, M. (2011). Location of rRNA transcription to the nucleolar components: disappearance of the fibrillar centers in nucleoli of regenerating rat hepatocytes. Cell Struct. Funct. 36, 49-56. doi: 10.1247/csf.10017

Ochs, R. L., Lischwe, M. A., Spohn, W. H., and Busch, H. (1985). Fibrillarin: a new protein of the nucleolus identified by autoimmune sera. Biol. Cell 54, 123-133. doi: 10.1111/j.1768-322X.1985.tb00387.x

Pendle, A. F., Clark, G. P., Boon, R., Lewandowska, D., Lam, Y. W., Andersen, J., et al. (2005). Proteomic analysis of the Arabidopsis nucleolus suggests novel nucleolar functions. Mol. Biol. Cell 16, 260-269. doi: 10.1091/mbc.E04-09-0791

Pontvianne, F., Blevins, T., Chandrasekhara, C., Mozgova, I., Hassel, C., Pontes, O. M., et al. (2013). Subnuclear partitioning of rRNA genes between the nucleolus and nucleoplasm reflects alternative epiallelic states. Genes Dev. 27, 1545-1550. doi: 10.1101/gad.221648.113

Pontvianne, F., Matia, I., Douet, J., Tourmente, S., Medina, F. J., Echeverria, M., et al. (2007). Characterization of AtNUC-L1 reveals a central role of nucleolin in nucleolus organization and silencing of AtNUC-L2 gene in Arabidopsis. Mol. Biol. Cell 18, 369-379. doi: 10.1091/mbc.E06-08-0751

Pruitt, R. E., and Meyerowitz, E. M. (1986). Characterization of the genome of Arabidopsis thaliana. J. Mol. Biol. 187, 169-183. doi: 10.1016/0022-2836(86) 90226-3

Raska, I., Reimer, G., Jarník, M., Kostrouch, Z., and Raska, K Jr (1989). Does the synthesis of ribosomal RNA take place within nucleolar fibrillar centers or dense fibrillar components? Biol. Cell 65, 79-82.

Raska, I., Shaw, P. J., and Cmarko, D. (2006). New insights into nucleolar architecture and activity. Int. Rev. Cytol. 255, 177-235. doi: 10.1016/S00747696(06)55004- 1

Rostovtsev, V. V., Green, L. G., Fokin, V. V., and Sharpless, K. B. (2002). A stepwise huisgen cycloaddition process: copper(I)-catalyzed regioselective "ligation" of azides and terminal alkynes. Angew. Chem. Int. Ed. 41, 2596-2599. doi: 10.1002/ 1521-3773(20020715)41:14<2596::AID-ANIE2596>3.0.CO;2-4

Scheer, U., Xia, B., Merkert, H., and Weisenberger, D. (1997). Looking at Christmas trees in the nucleolus. Chromosoma 105, 470-480. doi: 10.1007/BF02510484

Shibasaki, K., Uemura, M., Tsurumi, S., and Rahman, A. (2009). Auxin response in Arabidopsis under cold stress: underlying molecular mechanisms. Plant Cell 21, 3823-3838. doi: 10.1105/tpc.109.069906

Singh, B. N., Achary, V. M. M., Panditi, V., Sopory, S. K., and Reddy, M. K. (2017). Dynamics of tobacco DNA topoisomerases II in cell cycle regulation: to manage topological constrains during replication, transcription and mitotic chromosome condensation and segregation. Plant Mol. Biol. 94, 595-607. doi: 10.1007/s11103-017-0626-4

So, L. K., Cheung, S. K., Ma, H. L., Chen, X. P., Cheng, S. H., and Lam, Y. W. (2010). In situ labeling of transcription sites in marine medaka. J. Histochem. Cytochem. 58, 173-181. doi: 10.1369/jhc.2009.954511

Stoykova, A. S., Dabeva, M. D., Dimova, R. N., and Hadjiolov, A. A. (1985). Ribosome biogenesis and nucleolar ultrastructure in neuronal and oligodendroglial rat brain cells. J. Neurochem. 45, 1667-1676. doi: 10.1111/j. 1471-4159.1985.tb10521.x

Straatman, K. H., Trompetter, C. M., Schul, W., and Schel, J. H. N. (1996). Fluorescent labelling of nascent RNA reveals nuclear transcription doamins throughout plant cell nuclei. Protoplasma 192, 145-149. doi: 10.1007/ BF01273886
Tani, H., and Akimitsu, N. (2012). Genome-wide technology for determining RNA stability in mammalian cells: historical perspective and recent advantages based on modified nucleotide labeling. RNA Biol. 9, 1233-1238. doi: 10.4161/rna. 22036

Thompson, W. F., Beven, A. F., Wells, B., and Shaw, P. J. (1997). Sites of rDNA transcription are widely dispersed through the nucleolus in Pisum sativum and can comprise single genes. Plant J. 12, 571-581. doi: 10.1046/j.1365-313X.1997. 00571.x

Tornoe, C. W., Christensen, C., and Meldal, M. (2002). Peptidotriazoles on solid phase: [1,2,3]-triazoles by regiospecific copper(i)-catalyzed 1,3-dipolar cycloadditions of terminal alkynes to azides. J. Org. Chem. 67, 3057-3064. doi: $10.1021 /$ jo011148j

Turner, A. J., Knox, A. A., and Watkins, N. J. (2012). Nucleolar disruption leads to the spatial separation of key $18 \mathrm{~S}$ rRNA processing factors. RNA Biol. 9, 175-186. doi: 10.4161/rna.18811

Uddin, M., Altmann, G. G., and Leblond, C. P. (1984). Radioautographic visualization of differences in the pattern of $[3 \mathrm{H}]$ uridine and $[3 \mathrm{H}]$ orotic acid incorporation into the RNA of migrating columnar cells in the rat small intestine. J. Cell Biol. 98, 1619-1629. doi: 10.1083/jcb.98.5.1619

Unuma, T., Senda, R., and Muramatsu, M. (1972). Nature of the so-called fibrillar component in the segregated nucleolus after treatment of actinomycin D. J. Electron Microsc. 21, 60-70.

Uttamapinant, C., Tangpeerachaikul, A., Grecian, S., Clarke, S., Singh, U., Slade, P., et al. (2012). Fast, cell-compatible click chemistry with copper-chelating azides for biomolecular labeling. Angew. Chem. Int. Ed. 51, 5852-5856. doi: 10.1002/ anie.201108181

Waksmundzka, M., and Debey, P. (2001). Electric field-mediated BrUTP uptake by mouse oocytes, eggs, and embryos. Mol. Reprod. Dev. 58, 173-179. doi: 10.1002/1098-2795(200102)58:2<173::AID-MRD6>3.0.CO;2-2

Wansink, D. G., Schul, W., van der Kraan, I., van Steensel, B., van Driel, R., and de Jong, L. (1993). Fluorescent labeling of nascent RNA reveals transcription by RNA polymerase II in domains scattered throughout the nucleus. J. Cell Biol. 122, 283-293. doi: 10.1083/jcb.122.2.283

Wassermann, K., Newman, R. A., Davis, F. M., Mullins, T. D., and Rose, K. M. (1988). Selective inhibition of human ribosomal gene transcription by the morpholinyl anthracyclines cyanomorpholinyl- and morpholinyldoxorubicin. Cancer Res. 48, 4101-4106.

Watson, J. M., Platzer, A., Kazda, A., Akimcheva, S., Valuchova, S., Nizhynska, V., et al. (2016). Germline replications and somatic mutation accumulation are independent of vegetative life span in Arabidopsis. Proc. Natl. Acad. Sci. U.S.A. 113, 12226-12231. doi: 10.1073/pnas.1609686113

Yokoyama, R., Hirakawa, T., Hayashi, S., Sakamoto, T., and Matsunaga, S. (2016). Dynamics of plant DNA replication based on PCNA visualization. Sci. Rep. 6:29657. doi: 10.1038/srep29657

Yung, B. Y., Bor, A. M., and Chan, P. K. (1990). Short exposure to actinomycin $\mathrm{D}$ induces "reversible" translocation of protein B23 as well as "reversible" inhibition of cell growth and RNA synthesis in HeLa cells. Cancer Res. 50, 5987-5991.

Zankl, H., and Bernhardt, S. (1977). Combined silver staining of the nucleolus organizing regions and Giemsa banding in human chromosomes. Hum. Genet. 37, 79-80. doi: 10.1007/BF00293775

Zhang, X. H., Yu, X. Z., and Yue, D. M. (2016). Phytotoxicity of dimethyl sulfoxide (DMSO) to rice seedlings. Int. J. Environ. Sci. Technol. 13, 607-614. doi: 10.1007/s13762-015-0899-6

Conflict of Interest Statement: The authors declare that the research was conducted in the absence of any commercial or financial relationships that could be construed as a potential conflict of interest.

Copyright (@) 2018 Dvoráčková and Fajkus. This is an open-access article distributed under the terms of the Creative Commons Attribution License (CC BY). The use, distribution or reproduction in other forums is permitted, provided the original author(s) and the copyright owner are credited and that the original publication in this journal is cited, in accordance with accepted academic practice. No use, distribution or reproduction is permitted which does not comply with these terms. 